\title{
Peningkatan hasil belajar dalam pembelajaran tolak peluru melalui pendekatan metode bermain bola karet pada siswa
}

\author{
Nofriantoni Nofriantoni ${ }^{*}$ \\ SDN 08 Silaut Kecamatan Silaut
}

\begin{tabular}{l} 
Article Info \\
\hline Article history: \\
Received Des $30^{\text {th }}, 2020$ \\
Revised Jan $27^{\text {th }}, 2021$ \\
Accepted Feb18 $8^{\text {th }}, 2021$ \\
\hline
\end{tabular}

\section{Keyword:}

Hasil belajar Tolak peluru Basket

\begin{abstract}
Tujuan dari penelitian ini adalah untuk mengetahui peningkatan hasil belajar melalui pendekatan metode bermain bola karet dalam pembelajaran tolak peluru pada siswa kelas VI UPT SDN 08 Silaut Kecamatan Silaut Kabupaten Pesisir Selatan Tahun Pelajaran 2014/2015. Penelitian ini dilaksanakan di UPT SDN 08 Silaut Kecamatan Silaut Kabupaten Pesisir Selatan Kabupaten Pesisir Selatan, dengan subjek yang digunakan dalam penelitian adalah guru dan peserta didik di kelas VI dengan jumlah 24 orang peserta didik. Hasil penelitian menunjukan pada : Pada siklus I terjadi peningkatan rata-rata nilai unjuk kerja (psikomotor) menjadi 54,16, pemahaman konsep (kognitif) menjadi 66,66 dan sikap (afektif) menjadi 62,50. Namun pada siklus I ini ratarata siswa kelas VI UPT SDN 08 Silaut Kecamatan Silaut Kabupaten Pesisir Selatan hanya $6(25 \%)$ siswa sudah mencapai KKM dan $18(75 \%)$ siswa belum mencapai batas KKM. Pada siklus II juga terjadi peningkatan nilai unjuk kerja (psikomotor) menjadi 75,00, nilai rata-rata pemahaman konsep (kognitif) menjadi 70,83 dan rata-rata nilai sikap (afektif) meningkat menjadi 79,50 . Pada siklus I hanya $6(25 \%)$ siswa yang mengalami nilai kriteria ketuntasan minimal, dan setelah dilakukan evaluasi dan diberikan model pembelajaran pada sikuls II siswa mengalami peningkatan nilai rata-rata siswa. Pada siklus II $20(83,33 \%)$ siswa dari 24 siswa UPT SDN 08 Silaut Kecamatan Silaut Kabupaten Pesisir Selatan telah mencapai KKM dan 4 $(16,66 \%)$ siswa dari 24 siswa belum mencapai KKM.
\end{abstract}

(C) 2021 The Authors. Published by IICET.

This is an open access article under the CC BY-NC-SA license

(https://creativecommons.org/licenses/by-nc-sa/4.0

\section{Corresponding Author:}

Nofriantoni,

SDN 08 Silaut Kecamatan Silaut

Email: nofriantoni@gmail.com

\section{Pendahuluan}

Pendidikan merupakan salah satu kebutuhan bagi setiap manusia, baik pendidikan formal maupun non formal. Menurut Depdiknas (2003:4) pendidikan formal adalah jalur pendidikan yang terstruktur dan berjenjang yang terdiri atas pendidikan dasar, pendidikan menengah, dan pendidikan tinggi. Sedangkan pendidikan non formal adalah jalur pendidikan di luar pendidikan formal yang dapat dilaksanakan secara terstruktur dan berjenjang.

Pendidikan jasmani merupakan bagian integral dari pendidikan secara keseluruhan yang berisikan serangkaian materi pelajaran yang memberikan konstribusi nyata dalam kehidupan sehari-hari dalam upaya meningkatkan pertumbuhan dan perkembangan jasmani dan rohani peserta didik. Oleh karena itu penyelenggaraan penjas harus lebih dikembangkan ke arah yang lebih optimal sehingga peserta didik akan lebih kreatif, inovatif, terampil, dan memiliki kebiasaan hidup sehat dan aktif yang dapat menggiring pada 
kesegaran jasmani, serta memiliki pengetahuan dan pemahaman manusia (Buku Panduan Pembekalan Guru Kelas/Agama SD Menjadi Guru Berkualifikasi Guru Pendidikan Jasmani SD 2008:1).

Untuk mencapai tujuan pembelajaran di sekolah, perlu adanya dukungan dari faktor-faktor yang saling terkait antara lain faktor guru, siswa, kurikulum, sarana dan prasarana, lingkungan dan kondisi sosial. Dalam pelaksanaan pendidikan

Pendidikan jasmani di SD, materi yang diajarkan harus disesuaikan dengan kurikulum yang ada. Ketidak sesuaian materi dengan kurikulum yang ada dapat mempengaruhi ketidak optimalnya suatu tujuan pembelajaran. Dari kurikulum yang ada di SD terdapat berbagai macam materi pokok yang diajarkan pada peserta didik salah satunya yaitu tolak peluru. Untuk melaksanakan pembelajaran tolak peluru diperlukan alat yaitu peluru yang terbuat dari besi. Pada pembelajaran atletik biasanya akan terasa membosankan bagi siswa, karena siswa lebih suka dengan olahraga yang bersifat game atau kompetisi, sehingga diperlukan suatu metode pembelajaran ataupun modifikasi dalam pembelajaran. Pembelajaran tolak peluru di kelas VI UPT SDN 08 Silaut Kecamatan Silaut Kabupaten Pesisir Selatan masih belum berjalan secara efektif. Kenyataan di lapangan setiap pelaksanaan materi pembelajaran atletik, khususnya tolak peluru siswa kurang bersemangat dalam mengikuti aktivitas pembelajaran. Dari hasil observasi awal guru mengalami kesulitan dalam penyampaian materi tolak peluru supaya mendapatkan hasil yang maksimal. Hasil belajar siswa dalam pembelajaran tolak peluru, rata-rata siswa belum mencapai batas ketuntasan belajar.Kurangnya partisipasi siswa dalam mengikuti pembelajaran akan menurunkan tingkat keberhasilan siswa dalam belajar, oleh karena itu diperlukan suatu tindakan yang mampu melibatkan peran aktif siswa dalam mengikuti pembelajaran untuk mencapai tujuan pembelajaran tersebut.

Banyaknya jumlah siswa yang nilainya masih belum mancapai KKM merupakan tantangan dan perhatian peneliti untuk dicarikan solusi agar siswa tertarik pada olahraga atletik khususnya nomor tolak peluru sehingga prestasi belajarnya lebih meningkat. Salah satu faktor yang mempengaruhi banyak siswa yang nilainya kurang dari KKM adalah bagi siswa SD dengan berat peluru asli terlalu berat dan besar untuk digunakan dalam pembelajarn, sehingga siswa merasa kesulitan dalam cara memegang peluru, sikap awalan yang asal-asalan, cara menolak peluru tidak gerakan mendorong peluru tetapi melempar (ada gerakan lecutan pada pergelangan tangan) serta tidak diakhiri dengan gerakan lanjutan yang tepat. Dalam proses pembelajarannya dengan alat yang masih terbatas juga mempengaruhi sehingga anak masih menunggu dalam pembelajarannya yang menyebabkan anak merasa bosan.

Dengan kurikulum KTSP guru harus lebih kreatif dan lebih bisa melakukan inovasi dalam pembelajaran agar tecapai hasil yang maksimal. Jelas dari gambaran tersebut bahwa proses pembelajaran tolak peluru menjadi kurang efektif, dengan dibuktikan banyak siswa pada saat melakukan gerakan tolak peluru tidak dapat melakukan gerakan dengan baik dan benar karena peluru yang digunakan untuk pembelajaran terlalu berat dan model pembelajaranya kurang menarik minat siswa .

Modifikasi pendidikan jasmani dapat dilakukan dengan penekanan pada berbagai aspek, seperti materi, alat, ukuran, lapangan, bentuk, jumlah pemain. Dengan modifikasi pembelajaran bertujuan untuk meningkatkan prestasi belajar, minat atau partisipasi siswa dalam mengikuti pembelajaran, menciptakan suasana pembelajaran yang menyenangkan dan tidak membosankan bagi siswa.Sehingga dapat disajikan dengan cara yang lebih menarik, sehingga anak merasa lebih senang dan dapat mudah menyerap apa yang diajarkan oleh gurunya.

Berdasarkan permasalahan itulah yang menjadikan penulis untuk melakukan upaya dalam meningkatkan pembelajaran tolak peluru. Untuk mendapatkan hasil pembelajaran yang optimal diperlukan suatu metode atau pendekatan pembelajaran agar tujuan pembelajaran dapat terlaksana dengan baik, oleh karena itu sebagai seorang guru dituntut untuk mencari metode yang sesuai dengan karakteristik anak. Dari karakteristik tersebut, maka dalam penelitian ini peneliti mencoba mengaplikasikan pembelajaran melalui pendekatan bermain dalam pembelajaran tolak peluru, dan mencoba menuangkan gagasan penelitian dalam bentuk penelitian tindakan kelas yang akan peneliti beri judul "Peningkatan Hasil Belajar Dalam Pembelajaran Tolak Peluru Melalui Pendekatan Metode Bermain Bola Karet Pada Siswa Kelas VI UPT SDN 08 Silaut Kecamatan Silaut Kabupaten Pesisir Selatan Kab. Pesisir Selatan".

\section{Metode}

Penelitian ini merupakan Penelitian Tindakan Kelas (classroom action research). Subyek pada penelitian ini adalah siswa kelas VI UPT SDN 08 Silaut Kecamatan Silaut Kabupaten Pesisir Selatan Kabupaten Pesisir Selatan yang terdiri dari 12 siswa laki-laki dan 12 siswa perempuan. Penelitian Tindak Kelas (PTK) ini dilaksanakan 02 Maret 2020 s/d 02 Mei 2020 dan sesuai dengan jadwal pelajaran penjas orkes. Penelitian ini 
dilaksanakan minimal 2 siklus. Prosedur penelitian terdiri dari tahap perencanaan, tahap pelaksanaan, tahap pengamatan dan observasi serta refleksi. Instrumen pengumpulan data yang digunakan adalah lembar observasi atau pengamatan terhadap guru dan murid yang dapat digunakan untuk mengetahui keberhasilan proses pembelajaran tolak peluru. Data yang diperlukan dalam penelitian tindakan kelas ini berupa catatan tentang hasil pengamatan, penilaian, dan dokumentasi yang terekam selama proses pembelajaran berlangsung kemudian diolah dan disimpulkan. Teknik analisis data dalam penelitian tindakan kelas ini menggunakan analisis deskriptif berbentuk persentase.

\section{Hasil dan Pembahasan}

\section{Deskripsi Kondisi Awal}

Berdasarkan data yang diperoleh sebelum penelitian, kondisi awal siswa Kelas VI UPT SDN 08 Silaut Kecamatan Silaut Kabupaten Pesisir Selatan Tahun Pelajaran 2019/2020 dari hasil penilaian pelaksanaan pra siklus penelitian menunjukkan bahwa kemampuan rata-rata siswa memiliki kemampuan yang masih rendah. Banyak siswa yang nilainya belum tuntas. Hal ini dapat dilihat pada tabel data hasil penelitian berikut :

Tabel 1. Hasil rata-rata nilai pra siklus

\begin{tabular}{ccc}
\hline No & Aspek & Rata-rata Nilai \\
\hline 1 & Psikomotor & 45,83 \\
2 & Afektif & 54,16 \\
3 & Kognitif & 50,00 \\
\hline 4 & Nilai Akhir & 50,00 \\
\hline
\end{tabular}

\section{Deskripsi Siklus I}

\section{Perencanaan Tindakan}

Perencanaan tindakan sebaiknya dilakukan setiap sebelum melaksanakan tindakan siklus I, hal ini dilakukan agar pada saat pelaksanaan berjalan dengan lancar dan sesuai dengan yang diharapkan. Perencanaan dalam siklus I adalah sebagai berikut: 1) Melakukan identifikasi masalah dengan kolaborator dalam hal ini diadakan diskusi tentang rendahnya hasil belajar tolak peluru yang diperoleh siswa kelas VI UPT SDN 08 Silaut Kecamatan Silaut Kabupaten Pesisir Selatan sebagai subjek penelitian dan untuk mengambil langkah-langkah guna mengatasi hal tersebut. Diperoleh metode pendekatan modifikasi; 2) Merumuskan tindakan solusi dengan merencanakan pembelajaran tolak peluru dengan pendekatan modifikasi bermain menolakkan bola dengan sasaran ring dan menolak bola ke sasaran papan yang dibuat lingkaran; 3) Menyiapkan alat yang digunakan, berupa bola karet, ring (simpai), bambu, papan yang dibuat lingkaran, kapur.

\section{Pelaksanaan Siklus I}

Pelaksanaan siklus I pada hari Selasa tanggal 14 April 2020 di UPT SDN 08 Silaut Kecamatan Silaut Kabupaten Pesisir Selatan dengan jumlah objek penelitian 24 siswa. Melaksanakan pembelajaran tolak peluru awalan samping dalam bentuk modifikasi bermain menolak bola dengan sasaran ring dan menolak bola dengan sasaran papan yang dibuat lingkaran. Modifikasi pada permainan ini menekankan pada sikap awal, sikap menolak, dan sikap akhir, dengan rincian pelaksanaan kegiatan sebagai berikut: 1) Pendahuluan. Dilakukan dengan langkah-langkah sebagai berikut : (1) guru membariskan siswa menjadi 4 bersaf, (2) guru memimpin berdoa, (3) guru memberikan apersepsi dengan menceritakan kegiatan bermain menolak bola ke sasaran ring dan menolak bola ke sasaran papan yang dibuat lingkaran, (4) guru mempresensi siswanya, (5) pemanasan; 2) Kegiatan Inti. Bermain menolak bola dengan sasaran papan yang dibuat lingkaran. Aturan permainannya adalah sebagai berikut : (1) guru membawa siswa ke lapangan yang sesungguhnya dengan formasi 4 berbanjar, (2) setiap banjar disediakan 1 alat peraga sebagai alat pembelajaran berupa papan lemparan yang dibuat lingkaran, (3) jarak papan lemparan dari garis tolakan sejauh 2 meter, (4) tinggi papan lemparan 2 meter, (5) setiap banjar, disediakan 10 buah bola karet, (6) guru memerintahkan setiap siswanya menolak bola sebanyak 10 kali, dengan cara bergantian dengan awalan menyamping, (7) guru memberikan contoh gerakan, (8) guru mengkoreksi gerakan yang dilakukan siswa saat menolak, (9) guru memotivasi agar pelaksanaan kegiatan ini meriah, (10) guru mengadakan penilaian hasil belajar tolak peluru awalan samping; 3) Penutup. Dimulai dengan : (1) siswa tetap dalam formasi berbanjar untuk melakukan pendinginan berupa permainan, (2) siswa tetap dalam posisi duduk berbanjar, (3) guru menugaskan siswa satu permainan yaitu "tebak kata" dengan cara menulis kata di punggung teman yang berada di depannya, dan tidak diketahui oleh teman yang lain, (4) permainan ini dilaksanakan oleh masing-masing banjar atau kelompok. 


\section{Observasi}

Hasil pengamatan yang dilakukan kolaborator terhadap proses pembelajaran, setiap kemajuan yang terjadi baik pada siswa maupun suasana kelas dicatat dan diperoleh hasil sebagai berikut : 1) Guru melaksanakan pembelajaran sesuai dengan RPP; 2) Siswa masih mengalami kesulitan dalam melakukan gerakan menolakkan bola; 3) Suasana kelas selama proses pembelajaran menyenangkan, saling berebut bola dan berlomba menolakkan bola mengenai sasaran.

\section{Refleksi}

Berdasarkan hasil pengamatan penelitian, peneliti dan kolaborator melakukan relfeksi sebagai berikut : 1) Guru masih merasa kesulitan dalam menyampaikan tugas-tugas yang harus dilakukan siswa; 2) Sebagian siswa merasa kesulitan dalam melakukan menolakkan bola sampai mengenai sasaran; 3) Formasi siswa yang kurang tepat sehingga banyak waktu yang terbuang sehingga frekuensinya siswa melakukkan tindakan berkurang; 4) Guru menemukan modifikasi dengan menolakkan bola dengan sasaran ring. Dari hasil analisis dan evaluasi pelaksanaan siklus I diperoleh data nilai rata- rata siswa sebagai berikut :

Tabel 2. Hasil rata-rata nilai siklus I

\begin{tabular}{clcc}
\hline No & & Aspek & Rata-rata Nilai \\
\hline 1 & Psikomotor & 54,16 \\
2 & Afektif & & 66,66 \\
3 & Kognitif & 62,50 \\
\hline 4 & Nilai Akhir & 61,11 \\
\hline
\end{tabular}

Sasaran yang digunakan untuk proses pembelajaran yaitu lingkaran besar yang menyerupai ring yang di pasang di atas bambu. perencanaan siklus II adalah sebagai berikut : 1) Melakukan identifikasi masalah dengan kolaborator dalam hal ini diadakan diskusi tentang rendahnya hasil belajar tolak peluru awalan samping yang diperoleh siswa kelas VI UPT SDN 08 Silaut Kecamatan Silaut Kabupaten Pesisir Selatan sebagai subjek penelitian pada siklus I, maka perlu mengambil langkah-langkah guna meningkatkan hasil belajar tolak peluru. Diperoleh metode pendekatan modifikasi bermain menolakkan bola ke sasaran ring; 2) Merumuskan tindakan solusi dengan merencanakan pembelajaran tolak peluru dengan pendekatan modifikasi bermain menolakkan bola dengan sasaran ring; 3) Menyiapkan alat yang akan digunakan, berupa ring (simpai), bola karet, bambu, kapur.

\section{Pelaksanaan Siklus II}

Pelaksanaan siklus I di UPT SDN 08 Silaut Kecamatan Silaut Kabupaten Pesisir Selatan dengan jumlah objek penelitian 24 siswa. Melaksanakan pembelajaran tolak peluru awalan samping dalam bentuk modifikasi bermain menolakkan bola dengan sasaran ring. Modifikasi menolakkan bola sasaran ring ini menekankan pada sikap awal, sikap menolak, dan sikap akhir, dengan rincian pelaksanaan kegiatan sebagai berikut: 1) Pendahuluan. Dilakukan dengan langkah-langkah sebagai berikut : (1) guru membariskan siswa menjadi 4 bersaf, (2) guru memimpin berdoa, (3) guru memberikan apersepsi dengan menceritakan kegiatan bermain menolak bola ke sasaran ring dan menolak bola ke sasaran papan yang dibuat lingkaran, (4) guru mempresensi siswanya, (5) pemanasan; 2) Kegiatan Inti. Bermain menolak bola dengan sasaran ring, peraturannya sebagai berikut : (1) guru membawa siswa ke lapangan yang disana sudah dibuat dengan bentuk lapangan lingkaran dan ring yang berada di tengah- tengah lingkaran tersebut, (2) guru memerintahkan siswa mengelilingi lingkaran, (3) guru memberikan 1 bola pada setiap siswa, (4) guru memerintahkan siswanya untuk melempar bola ke ring yang ada di depannya dengan cara menolak, (5) guru memberikan contoh gerakan, (6) guru mengkoreksi gerakan yang dilakukan siswa, (7) siswa berlomba memasukan bola sebanyak mumgkin ke ring dengan cara menolak dengan awalan menyamping, (8) guru memotivasi agar pelaksanaan kegiatan ini meriah, (9) guru mengadakan penilaian hasil belajar tolak peluru awalan samping; 3) Penutup. Dengan langkah-langkah sebagai berikut : (1) siswa tetap dalam formasi berbanjar untuk melakukan pendinginan berupa permainan, (2) siswa tetap dalam posisi duduk berbanjar, (4) guru menugaskan siswa satu permainan yaitu "tebak kata" dengan cara menulis kata di punggung teman yang berada di depannya, dan tidak diketahui oleh teman yang lain, (5) permainan ini dilaksanakan oleh masing-masing banjar atau kelompok.

\section{Observasi}

Hasil pengamatan yang dilakukan kolaborator terhadap proses pembelajaran, setiap kemajuan yang terjadi, baik pada siswa maupun suasana kelas dicatat dan diperoleh hasil sebagai berikut: 1) Guru merasa berhasil dalam penyampaian tujuan pembelajaran tolak peluru; 2) Siswa merasa senang dan gembira mengikuti proses pembelajaran; 3) Suasana kelas selama proses pembelajaran menyenangkan; 4) Siswa lebih mengerti teknik menolak dengan baik dan benar. 
Refleksi

Berdasarkan hasil pengamatan peneliti dan kolaborator melakukan refleksi sebagai berikut : 1) Guru lebih jelas dalam menyampaikan tugas-tugas yang harus dilakukan siswa Proses pembelajaran lebih menyenangkan; 2) Frekuensi siswa dalam melakukan kegiatan bertambah. Dari hasil analisis dan evaluasi pelaksanaan siklus II diperoleh data nilai rata- rata siswa sebagai berikut :

Tabel 3. Hasil rata-rata nilai siklus II

\begin{tabular}{cllc}
\hline No & & Aspek & Rata-rata Nilai \\
\hline 1 & Psikomotor & & $\mathbf{7 5 , 0 0}$ \\
2 & Afektif & & $\mathbf{7 0 , 8 3}$ \\
3 & Kognitif & $\mathbf{7 9 , 1 6}$ \\
\hline 4 & Nilai Akhir & $\mathbf{7 5 , 1 1}$ \\
\hline
\end{tabular}

Dari hasil analisis pelaksanaan siklus II, terlihat adanya peningkatan rata-rata nilai siswa yang mencapai batas KKM yang telah ditetapkan yaitu 70. Berdasarkan indikator yang telah ditetapkan pada siklus II, menunjukkan bahwa indikator tersebut sudah melampaui KKM dibuktikan dengan 21 (87,50\%) siswa dari 24 siswa UPT SDN 08 Silaut Kecamatan Silaut Kabupaten Pesisir Selatan telah mencapai KKM dan 3 (12,50\%) siswa dari 24 siswa belum mencapai KKM.

\section{Pembahasan Siklus I \\ Pembahasan Siklus I}

Hasil penilaian kondisi awal yang menunjukan kemampuan siswa melakukan gerakan tolak peluru yang rendah, peneliti mencoba menerapkan metode pembelajaran dengan pendekatan modifikasi menggunakan bola. Kelemahan siswa yang mengakibatkan nilai rendah adalah tidak sebandingnya kekuatan otot lengan siswa dengan berat peluru, sehingga siswa merasa kesulitan dalam cara memegang peluru, sikap awalan yang asal-asalan, cara menolak peluru tidak gerakan mendorong peluru tetapi melempar (ada gerakan lecutan pada pergelangan tangan) serta tidak diakhiri dengan gerakan lanjutan yang tepat.

Pada saat wawancara, siswa menyatakan pembelajaran tolak peluru jarang dijumpai di sekolah maupun di masyarakat. Setelah dilaksanakan pembelajaran tolak peluru, guru merasa kesulitan dalam penyampaian materi tolak peluru walaupun dengan metode sesederhana mungkin $\mathrm{Hal}$ ini dibuktikan dengan motivasi siswa yang rendah dan prestasi belajar siswa belum mencapai batas ketuntasan belajar.

Pada kondisi tersebut, peneliti mencoba menerapkan metode bermain menolakkan bola karet ke sasaran berupa papan yang dibentuk lingkaran, dimana siswa tidak keberatan terhadap berat bola yang sesuai dengan kekuatan siswa. Setelah siswa melakukan gerakan tolak peluru dengan metode bermain ternyata terjadi peningkatan prestasi belajar. Data penilaian belum menunjukkan hasil yang diharapkan, tetapi terjadi peningkatan dari kondisi awal. Dari hasil penelitian dapat diketahui rata-rata nilai unjuk kerja (psikomotor) pada siklus I mengalami peningkatan. Nilai pemahaman konsep (kognitif) pada siklus I mengalami peningkatan karena pada siklus ini siswa mulai memiliki perhatian atau minat terhadap materi. Hal ini terjadi karena siswa merasa lebih mudah melakukan gerakan tolak peluru karena diawali dengan latihan yang mudah, menarik, serta beban alat yang ringan. Nilai sikap (afektif) juga menunjukan peningkatan hasil belajar. Siswa mulai tertarik melakukan gerakan tolak peluru karena siswa merasa gembira dalam melakukan tolak peluru. Dari hasil rata-rata nilai siklus I masih banyak siswa yang tidak mencapai kriteria ketuntasan minimal. Ini berarti tujuan pembelajaran berdasarkan indikator pencapaian KKM belum tercapai. Maka pembelajaran perlu dilanjutkan ke siklus II.

\section{Pembahasan Siklus II}

Pada siklus II ini siswa melakukan pembelajaran dengan pendekatan modifikasi dengan menolakkan bola dengan sasaran ring. Setelah melakukan pembelajaran dengan modifikasi menolakkan bola dengan sasaran ring dilakukan penilaian untuk mengambil data nilai unjuk kerja (psikomotor). Setelah adanya perubahan tersebut ternyata ada peningkatan nilai rata-rata unjuk kerja (psikomotor). Demikian pula halnya nilai pemahaman konsep (kognitif) juga mengalami peningkatan rata-rata nilai. Hal ini terjadi karena terkait dengan keaktifan siswa dalam mengikuti proses pembelajaran, yang nampak dalam hasil pengamatan menunjukkan 24 siswa mangalami peningkatan nilai hasil pembelajarannya dalam materi tolak peluru. Keaktifan siswa ini dipengaruhi oleh metode pembelajaran yang menggunakan bermain. Dengan bermain ini siswa semakin paham dengan konsep gerak tolak peluru, selain itu juga karena selama pembelajaran berlangsung suasana lebih menyenangkan dan tidak membosankan. Kondisi ini mendorong pula sikap siswa dalam mengikuti proses pembelajaran. Nampak pada peningkatan nilai rata-rata sikap (afektif) pada siklus ini. 
Dari ketiga aspek penilaian menunjukan bahwa rata-rata hasil belajar pada siklus II telah mencapai batas KKM dan hanya sedikit siswa yang belum mencpai KKM.

\section{Hasil Penelitian}

Pendekatan dengan metode modifikasi pada pembelajaran tolak peluru awalan samping dapat meningkatkan hasil belajar siswa kelas VI UPT SDN 08 Silaut Kecamatan Silaut Kabupaten Pesisir Selatan. Pada kondisi awal (pra siklus) rata-rata nilai unjuk kerja adalah 45,83, nilai pemahaman konsep (kognitif) adalah 54,16 dan nilai sikap (afektif) adalah 50,00. Dari hasil analisis pra siklus tidak ada siswa yang nilanya mencapai kriteria ketuntasan minimal.

Pada siklus I terjadi peningkatan rata-rata nilai unjuk kerja (psikomotor) menjadi 54,16, pemahaman konsep (kognitif) menjadi 66,66 dan sikap (afektif) menjadi 62,50 . Pada siklus I telah dilakukan tindakan untuk meningkatkan hasil belajar siswa dalam pembelajaran tolak peluru dengan menggunakan metode modifikasi menolakkan bola ke sasaran papan yang berupa lingkaran. Namun pada siklus I ini rata-rata siswa kelas VI UPT SDN 08 Silaut Kecamatan Silaut Kabupaten Pesisir Selatan hanya 6 (25\%) siswa sudah mencapai KKM dan 18 (75\%) siswa belum mencapai batas KKM.

Pada siklus II juga terjadi peningkatan rata-rata nilai, yaitu rata-rata nilai unjuk kerja (psikomotor) menjadi 75,00 ,nilai rata-rata pemahaman konsep (kognitif) menjadi 70,83 dan rata-rata nilai sikap (afektif) meningkat menjadi 79,50. Pada siklus II ini metode pembelajaran menggunakan modifikasi menolakkan bola dengan sasaran ring, siswa lebih aktif dan lebih senang dalam suasana berusaha untuk memasukkan bola sebanyak mungkin ke ring. Dari hasil model pembelajaran yang dilakukan pada siklus II, rata-rata nilai siswa mengalami peningkatan dan rata-rata nilai siswa mencapai KKM yang telah ditentukan. Pada siklus I hanya 6 (25\%) siswa yang mengalami nilai kriteria ketuntasan minimal, dan setelah dilakukan evaluasi dan diberikan model pembelajaran pada sikuls II siswa mengalami peningkatan nilai rata-rata siswa. Pada siklus II 20 $(83,33 \%)$ siswa dari 24 siswa UPT SDN 08 Silaut Kecamatan Silaut Kabupaten Pesisir Selatan telah mencapai KKM dan $4(16,66 \%)$ siswa dari 24 siswa belum mencapai KKM.

Setelah dilakukan penelitian berkaitan dengan upaya meningkatkan hasil belajar siswa dalam pembelajaran tolak peluru awalan samping melalui model pembelajaran dengan pendekatan bermain bola karet pada siswa kelas UPT SDN 08 Silaut Kecamatan Silaut Kabupaten Pesisir Selatan, diperoleh hasil berupa nilai rata-rata per aspek dan rata-rata hasil belajar yang berasal dari penggabungan ketiga aspek seperti terlihat pada tabel berikut :

Tabel 4. Hasil nilai rata-rata keseluruhan siswa kelas UPT SDN 08 Silaut Kecamatan Silaut Kabupaten Pesisir Selatan

\begin{tabular}{clccc}
\hline No & \multicolumn{1}{c}{ Aspek } & Nilai Pra Siklus & Nilai Siklus I & Nilai Siklus II \\
\hline $\mathbf{1}$ & Psikomotor & 45,83 & 54,16 & $\mathbf{7 5 , 0 0}$ \\
$\mathbf{2}$ & Afektif & 54,16 & 66,66 & $\mathbf{7 0 , 8 3}$ \\
$\mathbf{3}$ & Kognitif & 50,00 & 62,50 & $\mathbf{7 9 , 1 6}$ \\
\hline $\mathbf{4}$ & Nilai Akhir & $\mathbf{5 0 , 0 0}$ & $\mathbf{6 1 , 1 1}$ & $\mathbf{7 5 , 1 1}$ \\
\hline
\end{tabular}

\section{Simpulan}

Berdasarkan hasil penelitian tindakan kelas dengan dua siklus dan diadakan analisis dapat disimpulkan bahwa metode penerapan pembelajaran tolak peluru melalui pendekatan metode bermain dengan bola karet dapat meningkatkan hasil belajar tolak peluru awalan samping kelas VI UPT SDN 08 Silaut Kecamatan Silaut Kabupaten Pesisir Selatan Tahun Pelajaran 2019/2020. Proses pembelajaran berjalan dengan efektif dan siswa lebih aktif dalam melaksanakan penugasan yang diberikan oleh guru. Peningkatan hasil belajar siswa dapat dilihat melalui jumlah siswa yang mencapai nilai kriteria ketuntasan minimal.

\section{Referensi}

Agus Kristiyanto. (2010). Penelitian Tindakan Kelas (PTK). Surakarta : UNS Press.

Agus Suprijono. (2009). Cooperative learning. Yogyakarta : Pustaka Pelajar.

Azhar Arsya. (2006). Media Pelajaran. Jakarta : PT Raja Grafindo Persada.

Darsono, Max. (2000). Belajar dan Pembelajaran. Semarang:IKIP Semarang Press.

Depdiknas. (2003). Undang - Undang Republik Indonesia No 20 Tahun 2003TentangSisitam Pendidikan Nasional. Jakarta : Cemerlang 
Dewi Salma Prawiladilaga. (2007). Prinsip Desain pembelajaran. Jakarta : Kencana Prenada Media Group.

Dimyati Mahmud. (1993). Psikologi Pendidikan. Yogyakarta : UPP IKIP Yogyakarta

Eka Pribadi, dkk. (1943). Pendidikan Jasmani dan Kesehatan. Jakarta : Yudhistira.

Kelompok Kerja Nasional Garuda Mas. 2000. Pemanduan Bakat dan Pembinaan Usia Dini. Jakarta : Depdiknas.

Khomsin. (2005). Atletik I. Semarang : Universitas Negeri Semarang Press.

Mochamad Djumidar A.Widya. (2004). Belajar berlatih Gerak-Gerak Dasar Atlet Dalam

Bermain. Jakarta: PT. RajaGrafindo Persada.

Mohamad Ali. (1987). Penelitian Pendidikan Prosedur dan Strategi. Bandung : Angkasa Bandung

M Sakir, Genikarsa. (1989). Pendidikan Jasmani 6. Klaten : PT Intan Pariwara.

Mulyono Abdurrahman. (1999). Pendidikan Bagi Anak Berkesulitan Belajar.

Jakarta : Rineka Cipta.

Nurhadi.2003. Pembelajaran Kontekstual dan Penerapannya dalam KBK.Malang : KBK.Malang

Pardjono, dkk. (2007). Panduan Penelitian Tindakan Kelas. Yogyakarta : Lembaga Penelitian UNY.

Sumadi Suryabrata. (2004). Psikologi Pendidikan. Jakarta : PT Raja Grafindo Persada.

Tim Penulis Buku Psikologi Pendidikan. (1993). Psikologi Pendidikan.

Yogyakarta : UPP IKIP Yogyakarta.

Tisnowati Tamat, dkk. (2005). Pendidikan Jasmani dan Kesehatan. Jakarta : Universitas Terbuka.

Wina Sanjaya. (2007). Strategi Pembelajaran. Bandung : Kencana Prenada Media Group.

Yoyo Bahagia, Adang Suherman. (2000). Prinsip-Prinsip Pengembangan dan Modifikasi Cabang Olahraga. Depdiknas.

Yudha. (2001). Pembelajaran Atletik di sekolah Dasar. Jakarta : Depdiknas. (2004). Dasar-dasar Keterampilan Atletik. Jakarta : Depdiknas. 